\title{
Testemunhos latino-americanos em memória de Jesús Martín-Barbero
}

Latin-American Testimonials in Memory of Jesús Martín-Barbero

\author{
RA ÚL FUENTES NAVARROa \\ Universidad de Guadalajara, Departamento de Estudios de la Comunicación Social. Guadalajara - \\ Jalisco, México \\ Universidad Jesuita de Guadalajara (Iteso), Departamento de Estudios Socioculturales. \\ Guadalajara - Jalisco, México
}

$\mathrm{P}$ OUQUÍSSIMOS PESQUISADORES SOCIAIS latino-americanos, e menos ainda acadêmicos da comunicação, alcançaram um reconhecimento tão amplo, dentro e fora da região, como o cultivado por Jesús Martín-Barbero ao longo de sua longa e destacada carreira. Espanhol de nascimento, mas latino-americano por opção, viveu e trabalhou a maior parte de sua vida na Colômbia, e de lá participou de inúmeras viagens pelo mundo, de publicações em diferentes idiomas e nos debates (e combates) fundamentais do campo da comunicação durante as últimas cinco décadas. A sua obra científica, fecunda e polêmica, é uma referência indispensável no estudo da comunicação e um legado que transcende a sua presença e amplia a sua influência, apesar de "os tempos não serem [ainda] de síntese", "no campo da mediação de massa, de seus dispositivos de produção e seus rituais de consumo, seus aparatos tecnológicos e suas encenações espetaculares, seus códigos de montagem, de percepção e reconhecimento" (Martín-Barbero, 1987, p. 9).

Os quatro testemunhos apresentados a seguir foram escritos por acadêmicos latino-americanos que, como tantos outros, gozaram da estreita amizade de Jesús Martín-Barbero e valorizam seu trabalho e seu legado com contribuições de grande valor, dignas de continuarem a ser discutidas e adotadas no campo, porque “investigar a comunicação tornou-se um 'lugar' estratégico para reimaginar o sentido e o alcance do pensamento crítico tanto em sua relação epistemológica quanto em sua inserção política em nossas sociedades” (Martín-Barbero, 2002, p. 455).

Muitos outros testemunhos a respeito da partida de Jesús, que foram expressos em diferentes meios de comunicação, poderiam ter sido incorporados aqui

${ }^{\text {a }}$ Professor-investigador Titular do Departamento de Estudios de la Comunicación Social da Universidad de Guadalajara e Professor Emérito do Iteso (Universidad Jesuita de Guadalajara). Membro da Academia Mexicana de Ciências e Pesquisador Emérito do Sistema Nacional de Investigadores. Orcid: https:// orcid.org/0000-0001-64948122. E-mail: raul@iteso.mx 
como evidência da forte marca de seu impacto em várias gerações de estudiosos latino-americanos. Por razões de espaço, incluem-se como exemplos os testemunhos de Eduardo Gutiérrez, Carlos Alberto Scolari, Omar Rincón e Néstor García Canclini.

\section{PENSAR EM MOVIMENTO: RELER OFÍCIO DE CARTÓGRAFO}

\section{EDUARDO GUTIÉRREZ b}

Pontificia Universidad Javeriana, Departamento de Comunicación. Bogotá - Distrito Capital, Colômbia

${ }^{\mathrm{b}}$ Doutor em educação, professor do Departamento de Comunicación da Pontificia Universidad Javeriana. Orcid: https://orcid.org/0000-00025116-676X. E-mail: gilberto. gutierrez@javeriana
Como se lê o texto do cartógrafo que narra a sua própria viagem? O território sofreu muitas mudanças e é lido como um velho mapa da cidade destruída com fragmentos e ruínas visíveis? É explorado arqueologicamente para captar os sinais e vestígios de lugares que outrora foram territórios habitados? É interpretado a partir do presente para encontrar os sinais antecipados de alguma catástrofe ou os indicadores de um futuro previsto nunca realizado? Percebe-se uma genealogia então imprevisível a partir das rachaduras e vazios, é então e hoje difundida como uma premonição das geografias emergentes?

Voltar ao Ofício de Cartógrafo (Martín-Barbero, 2002) quase 20 anos após sua publicação é sobretudo habitar o modo de pensar em movimento de Jesús Martín-Barbero. Acompanhá-lo na viagem. Se De los Medios a las Mediaciones (Martín-Barbero, 1987) nos convidou a entender o próprio mapa, aqui se tem a oportunidade de perder o objeto - o mapa - para ganhar o processo: a jornada. Não é à toa que já na introdução ele nos faz ver sua dupla condição de cartógrafo e cronista: de pensador envolvido.

Pensar em movimento é, em primeiro lugar, poder retomar os próprios trajetos e passar, no presente, do debate que se deu nos anos 1970 e 1980 a partir das questões do discurso e do poder a um modo de reconstruir historicamente os próprios debates numa conjuntura a 30 anos de distância e verificar os aspectos, que apesar da longa batalha, ainda são tensões constitutivas no campo da comunicação: os pragmatismos utilitaristas e os ideologismos deterministas. A partir de aí indicar a saída: a superação dos dualismos a partir da cultura e nesta pelo popular.

Isto é, o traçado da travessia confirma algumas das marcas profundas da geografia e, ao mesmo tempo, revela o peso que sobrevive na forma como continua a pensar e a agir hoje. É pensar em si mesmo e na mudança no campo do saber emergente. Talvez o motivo específico que o leva a concluir esse balanço na perspectiva dos anos 1980 seja a tensão entre tecnologias e apropriações, entre 
determinismos e usos, que conclui a seção, deixando em aberto o debate que, sem dúvida, sugere a forma como a modernização e as modernidades divergentes vão configurando as décadas seguintes no contexto latino-americano.

Sob o mesmo signo, na seção dedicada aos anos 1990, o pensamento em movimento de Jesús Martín-Barbero retoma um passado mais recente, seleciona e monta peças de diferentes quebra-cabeças e compõe um quadro provocativo em que, à maneira da montagem cinematográfica, coloca diversas formas e densidades em tensão. Ao contrapor planos, três tópicos são delineados: um balanço da formação do campo acadêmico naquela década; uma nova síntese conceitual; e uma agenda para o final do século. Todos os três pontos merecem desenvolvimento.

O primeiro é, sobretudo, o relato contraditório de uma década que consolida a centralidade da comunicação como questão fundamental da sociedade e ao mesmo tempo vê seu sentido político e transformador se diluir em meio às burocracias, ao mercado e à asfixia da voraz institucionalidade. O segundo, que constitui o próprio cerne do livro, em breves vinte páginas apresenta um esboço do que pode ser o modo de pensar as mutações de fim de século e a atualização do modo martín-barberiano de pensar as mediações: as relações entre regimes de tecnicidades, institucionalidades, ritualidades e socialidades. O terceiro é traçar uma agenda que seja o desenho do conjunto de cenários no quais, nas duas primeiras décadas do século XXI, Martín-Barbero continuou trabalhando para pensar o presente e compreender e agir no sentido daquilo que se vive no próprio momento da experiência. A saber: as globalizações em relação aos modos de ver, as desterritorializações e os mundos emergentes que habitamos; a mutação da experiência, do sensorium e da vida urbana em meio a fluxos e redes; a mediatização da política em contraste e conexão com as políticas de comunicação; os desafios para a educação a partir da comunicação; e a ainda pendente construção e reconhecimento do espaço cultural latino-americano.

Lá, a cartografia que não define territórios absolutos, mas é o registro ao pé do chão da vivência nos relevos, ousando pensar em lugares mutáveis e expor uma agenda atravessada pelos debates do contemporâneo. Acompanhar as mudanças. Por isso, possui força reflexiva e até poética a opção de finalizar o livro com um espaço de diálogo no qual se reúne a coleção de prólogos escritos desde os anos 1980. É, ao mesmo tempo, uma viagem por uma antologia de textos e autores fundamentais para a cartografia habitada da comunicação-cultura na América Latina. Placas de sinalização, pontos de encontro que também se traçam no mapa e falam do percurso da comunicação na cultura. Comparado com outras peças da bibliografia martín-barberiana, este é um livro para pensar com o autor, para acompanhá-lo no trajeto, para ser testemunha e abraçar 
contradições e dúvidas, sem receio. Contemplar a paisagem ou descobrir o vestígio. Acolher um modo de ver.

É assim que o Ofício de Cartógrafo (Martín-Barbero, 2002), expressão do pensamento em movimento que marca o legado de Jesús Martín-Barbero, tem essa característica de trabalho em progresso, que não significa apenas assumir, avaliar e examinar a mudança no próprio pensamento - temática valiosa em si mesma -, mas é sobretudo a disposição de entrar na dialética entre os fatos teimosos e os modos de pensar. Chaves para ver com os outros, sair dos dualismos ou reler, desterritorializar e atender às mutações estão vivas e são evidenciadas em uma obra que não é um atlas, mas uma forma de explorar e exercitar a cartografia como saber artesanal, precário e mutante. Palimpsesto polifônico de mapas em construção constante.

\section{LER JM-B}

c Professor da Universitat Pompeu Fabra, em Barcelona. Coordenador do Programa de Doutorado em Comunicação. Orcid: https://orcid.org/00000002-7792-0345. E-mail: carlosalberto.scolari@upf.edu
CARLOSA. SCOLARI ${ }^{\text {c }}$

Universitat Pompeu Fabra, Departamento de Comunicación, MEDIUM Research Group. Barcelona Catalunha, Espanha

Como abordar a obra de Jesús Martín-Barbero (JM-B)? Como interpretar um corpus textual rico tanto em sua forma quanto em seu conteúdo, que passou por diferentes momentos e conheceu diferentes interlocutores a cada etapa? Quando JM-B começou a delinear seu pensamento no fim dos anos 1970, muitos investigadores da escola crítico-reprodutivista então hegemônica no continente franziram a testa diante de uma proposta que deslocava a discussão da dupla qualidade dos meios/ideologia para o eixo cultura de massa/cultura popular. Alguns investigadores, entretanto, preferem citar o JM-B anterior ao calafrio epistemológico, ou seja, o que continuava a transmitir na frequência de onda da tradicional crítica ideológica de matriz francesa. Não se deve se enganar: JM-B não é AM.

Se alguns o leem como se fosse a nova encarnação da denúncia ao poder monopolista dos meios, convém lembrar que foi precisamente JM-B quem nos ensinou a escapar da razão dualista e a não cair em abordagens maniqueístas. Se aprendemos algo de (com) JM-B é a olhar os interstícios, a investigar as zonas de fronteira (NGC dixit) e a nos inserirmos sem medo nesses territórios culturais que não são sólidos nem líquidos, mas turvos e lodosos. Conhecendo a sua devoção pelos jogos de palavras e seu DNA anarquista, não tenho dúvidas em afirmar que Jesús nos ensinou a nos mantermos à distância das religiões teóricas. 
No meu caso, o olhar de JM-B serviu para repensar a relação entre os (novos) meios e as culturas colaborativas que emergem nas redes digitais; ao mesmo tempo, me permitiu escapar do culto aos new media tão em voga desde o início da revolução do silício. Traduzido na linguagem de JM-B, tratava-se de perder o objeto (new media) para recuperar o processo (hipermediações). Como escrevi em um livro publicado em 2008, "sem mediações não haveria hipermediações" (Scolari, 2008, p. 113). E, sem a obra de JM-B, hoje estaríamos muito mais perdidos e desprovidos de categorias analíticas fundamentais para compreender o que está ocorrendo no mundo dos meios, da comunicação e da cultura.

\section{O ESTILO MARTÍN-BARBERIANO}

O M A R R N CÓN d

Universidad de los Andes, Maestría en Periodismo y en Humanidades Digitales. Bogotá - Distrito Capital, Colômbia

Há um modo de pensar martín-barberiano. Um estilo que se revela em suas formas de nomear, escrever, imaginar e se apaixonar. Seu modo é a partir do sul, mas em diálogo com o norte, o leste, os diversos suis.

Esse estilo é enunciado em mantras que se convertem em um tutorial para intervir no campo da comunicação e da cultura: é preciso perder o objeto para ganhar o processo; investigar a comunicação é ver com os outros; requer passar dos meios às mediações; não se deve buscar os efeitos nem as audiências, mas os reconhecimentos; precisamos passar do raciocinar e ilustrar para o narrar; enquanto a televisão comercial é feita para o consumidor, a televisão pública dirige-se ao cidadão; a internet não é uma revolução da distribuição (à Gutemberg), mas da escrita, é por isso que estamos escrevendo de maneira oralvisual...

Mantras da comunicação que repetimos, mas não sabemos muito bem o que significam. E não sabemos por que o modo martín-barberiano consistia em provocar, explodir, incomodar, mas não definir: deixar os sentidos na aventura, no fluxo, no ensaio. O estilo martín-barberiano se concretiza em cinco campos de experimentação:

Habitar a contradição da modernidade. Filho da modernidade e de seu iluminismo, de seu pensamento crítico, de sua perspectiva de direitos, sua luta original é ser moderno, lutando contra seus sentidos e hipocrisias, explodindo-o para torná-lo menos branco, menos ocidental, menos masculino. Estourando com a modernidade para produzir uma jodernidad ${ }^{1}$, algo mais saboroso e bonito nos sabores femininos, afros, indígenas, gays, trans, jovens...

Aprender do popular. O popular, o dos territórios da identidade e da política, mas também o dos meios massivos e das músicas para dançar, foi a sua tática
${ }^{\mathrm{d}}$ Professor associado da Universidade de Los Andes e diretor do Centro de Estudios en Periodismo e do Mestrado em Periodismo da mesma universidade. Orcid: http:// orcid.org/0000-0002-86902253.E-mail: orincon@ uniandes.edu.co
${ }^{1}$ Em outro texto, Rincón (2018) define assim esse termo: "algo como a modernidade que se ferrou [jodió], rompeu, explodiu... e também a maneira lúdica, com humor, irônica, paradoxal com que a América Latina assume e pratica a modernidade" (p. 224) (N. do T.). 
para intervir na Cultura Moderna e Ocidental, mas também para questionar a cultura pop, a indústria cultural e a obsessão que têm pelo mercado. E é sua proposta para pensar e produzir conhecimento em histórias, para entender que as pessoas das classes baixas têm uma experiência sem discurso que se deixa dizer apenas no relato.

Escutar a diversidade. Sua luta permanente é contra os dualismos morais (isso de Deus e família) e os maniqueísmos ideológicos (isso de esquerdas e direitas). Sua busca permanente é habitar a ambiguidade e a diversidade, não estar de acordo nem consigo mesmo, desafiando-se a sair daquele conforto moral e superior que é a academia e a teoria.

Ver com os outros. Manter as perguntas habituais, mas sempre mudando o lugar delas. Olhar a partir do outro lado, ouvir os jovens, ser fã dos experimentos e ter a crença de que, a partir de baixo, das comunidades, dos outros, se pensa/ imagina mais bonito. E é por isso que sua proposta de ir do raciocínio e do ilustrar ao narrar (contar-enunciar, contar-narrar, dar atenção e ser levado em conta).

Propor as mediações como a articulação entre os movimentos do industrial, do popular e do político.

O estilo martín-barberiano, por fim, propõe que todo comunicador deve fazer três coisas: pensar com a própria cabeça, ter o que dizer e conseguir escutar.

\title{
"DEVEMOS DAR MUITOS ECOS AO QUE JESÚS NOS DISSE..."
}

\author{
NÉSTOR GARCÍA CANCLINT e
}

Universidad Autónoma Metropolitana Iztapalapa. Cidade do México, DF, México

${ }^{2}$ Extrato de uma conversa com Omar Rincón, realizada na Cidade do México, em $1^{\circ}$ de julho de 2021.

${ }^{e}$ Professor emérito da Universidad Autónoma Metropolitana de México e pesquisador emérito do Sistema Nacional de Investigadores desse país. Orcid: https://orcid.org/00000002-5777-8230. E-mail: drngc197@hotmail.com
Omar Rincón: Que coisas deixavam Jesús incomodado?

Néstor García Canclini: Poderia falar de mal-entendidos e alguns que enfadavam um pouco Jesús. Por exemplo, quando ele escreveu uma introdução para uma reedição de De los Medios a las Mediaciones (Martín-Barbero, 1987), ele me disse que muitas pessoas que haviam lido o livro não queriam comprar a nova edição, porque pensavam que já o conheciam, e então continuaram questionando-o sobre posições que ele havia modificado ou esclarecido na introdução. Sim, escrever um livro como esse deixa uma marca e, mesmo entre aqueles que irão ler outras obras depois, sobre temas diversos, por exemplo, a transnacionalização da cultura e as tecnologias mais recentes, as audiências e os públicos, poucos captaram as mudanças. Jesús, por sua vez, percebia claramente que era preciso repensar para entender a contemporaneidade. 
OR: Entre esses mal-entendidos, creio que Jesús é muito citado, ele é como um popstar, mas é pouco lido. Todo mundo fala sobre ele, mas poucas pessoas o leram...

NGC: Isso acontece muito. A desgraça de um autor ter prematuramente a ressonância que Jesús teve com De los Medios a las Mediaciones (Martín-Barbero, 1987) é que, ainda que muitos o leiam, eles também o transformam em uma marca. Num encontro que assistimos juntos, faz muito tempo, em Montevidéu, convivemos muito, mas Jesús ficou muito chateado porque o obrigavam a ir a duas ou três entrevistas por dia na televisão e com jornalistas da mídia impressa, e depois tinha que dar uma conferência massiva de duas horas e meia. Ele me disse "Não vou mais aceitar ser tratado assim. Levaram-me a um programa de televisão onde o entrevistador não tinha lido nada meu e depois levaram-me a jornalistas que, sim, me haviam lido e eu já estava cansado".

OR: Tanto você quanto Jesús são intelectuais. Acho que há uma diferença com outros acadêmicos, porque os intelectuais pensam o mundo politicamente. Nisso, Jesús e você são semelhantes.

NGC: $E$ isso tem crescido à medida que aumenta o número de acadêmicos, embora poucos alunos consigam trabalhar mais tarde na universidade, porque não são criadas vagas novas. Mas, parece-me que há várias décadas, mesmo em países onde os intelectuais eram ouvidos como vozes públicas, e era possível fantasiarem que podiam orientar a direção da opinião, como na França, hoje não temos mais essa possibilidade. Desde a difusão massiva da televisão, quase ninguém se deixa guiar pelo que dizem os intelectuais. No entanto, em alguns países latino-americanos, alguns ainda acreditam que podem ser interlocutores influentes para mudar o rumo da votação no próximo domingo. É curioso que isso aconteça quando menos jovens ingressam nas universidades, quando a maioria de nós que continua investigando são vozes que vêm de outra época. Acredito que Jesús não se iludiu com esse poder de influência. Soube perceber situações em que poderia falar e dizer algo que ia ser ouvido, por exemplo, sobre a nova constituição colombiana, a de 1991. Mas ele não estava interessado em ser convidado para ir à televisão esta semana. Ele também fez contribuições para o campo político ajudando a entender a relação entre cultura e educação. Ele estava muito atento ao que os meios diziam sobre essas questões, mas não estava ansioso para ser visto na televisão ou nas redes. Em vez disso, ele aparecia pelos discípulos e leitores que o citaram. M 


\section{REFERÊNCIAS}

Martín-Barbero, J. (1987). De los medios a las mediaciones: Comunicacion, cultura $y$ hegemonia. Gustavo Gili.

Martín-Barbero, J. (2002). Oficio de cartógrafo. Travesías latinoamericanas de la comunicación en la cultura. Fondo de Cultura Económica.

Scolari, C. (2008). Hipermediaciones. Elementos para una teoría de la comunicación digital interactiva. Gedisa.

Rincón, O. (2018). Ensayo en forma de tuits: Sentidos y relatos de Martín-Barbero. Intexto, (43), 223-236. http://dx.doi.org/10.19132/1807-8583201843.223-236 